\title{
Roles of Acceptor Guests in Tuning Organic Solar Cell Property Based on an Efficient Binary Material System with a Nearly Zero
}

\section{Hole Transfer Driving force}

Xiaofang $\mathrm{Li}^{\mathrm{a}, \mathrm{c} \ddagger}$, Ming-Ao Pan ${ }^{\mathrm{a}, \mathrm{d} \ddagger}$, Tsz-Ki Lau ${ }^{\mathrm{e} \ddagger}$, Wanru Liu ${ }^{\mathrm{c}}, \mathrm{Kun} \mathrm{Li}^{\mathrm{f}}$, Nannan Yao ${ }^{\mathrm{g}}$, Fugang Shen $^{\mathrm{c} *}$, Shuying Huo ${ }^{\mathrm{c}}$, Fengling Zhang ${ }^{\mathrm{g}}$, Yishi Wu ${ }^{\mathrm{f} *}$, Xuemei $\mathrm{Li}^{*}{ }^{, b}$, Xinhui Lu ${ }^{\mathrm{e}}, \mathrm{He}$ Yan ${ }^{\mathrm{d}}$, Chuanlang Zhan ${ }^{\mathrm{a} * \mathrm{iD}}$

${ }^{a}$ Key Laboratory of Excitonic Materials Chemistry and Devices (EMC\&D), College of Chemistry and Environmental Science, Inner Mongolia Normal University, Huhhot 010022, China. E-mail: clzhan@iccas.ac.cn; clzhan@imnu.edu.cn (C.Z.) ORCID ${ }^{\text {iD }}$ 0000-0001-5127-0973.

${ }^{\mathrm{b}}$ School of Chemistry \& Chemical Engineering, Linyi University, Linyi 276000, China. E-mail: xuemei_li@yeah.net(X.L), ORCID 0000-0002-8303-8121.

${ }^{\mathrm{c}}$ College of Chemistry and Environmental Science, Hebei University, Baoding 071002, China. E-mail: shenfg@hbu.edu.cn (F.S.).

${ }^{\mathrm{d}}$ Department of Chemistry, The Hong Kong University of Science and Technology, Clear Water Bay, Kowloon, Hong Kong, China.

${ }^{\mathrm{e}}$ Department of Physics, Chinese University of Hong Kong, New Territories, Hong Kong, China.

${ }^{\mathrm{f}}$ Beijing Key Laboratory for Optical Materials and Photonic Devices, Department of Chemistry, Capital Normal University, Beijing 100048, China. E-mail: yswu@iccas.ac.cn (Y.W.)

${ }^{\mathrm{g}}$ Biomolecular and Organic Electronics, Department of Physics, Chemistry and Biology, Linköing University, 58183, Linköing, Sweden. 


\section{Experimental details}

\subsection{Materials and Instruments}

The materials of PM6, IT-4F, Y6, $\mathrm{PC}_{71} \mathrm{BM}$ and PDINO were purchased from Solarmer and Shenzhen Ruixun company. PEDOT:PSS (Baytron Clevios P VP AI 4083, Germany) was obtained from Heraeus Group. Absorption spectra were measured on a Hitachi U-3010 UV-vis spectrophotometer at room temperature. Transmission electron microscopy (TEM) measurements were performed on a JEM-2100F transmission electron microscope operated at $200 \mathrm{kV}$. The thickness of the solid films was measured using a Dektak Profilometer.

\subsection{Sample preparations and characterizations}

Film samples for measurements of absorption and TEM were all prepared atop the pre-coated ITO/PEDOT:PSS substrate via the spin-coating method. The pure donor film was spun-cast from an chlorobenzene $(\mathrm{CB})$ solution of $10 \mathrm{mg} / \mathrm{ml}$ and the pure acceptor film was spin-coated from a chloroform solution of $10 \mathrm{mg} / \mathrm{ml}$. All the blend films were fabricated under the optimal conditions for preparations of optimal solar cells, which are shown in Section 1.3. For TEM, the films were obtained by transferring the floated blend films from the water onto the $\mathrm{Cu}$ grid.

\subsection{Solar cell Device fabrications and measurements}

Indium tin oxide (ITO) coated glass substrates were pre-cleaned with deionized water, CMOS grade acetone and isopropanol in turn for 20 minutes, followed by treating with UV-ozone for 30 minutes. Atop the cleaned ITO surface a PEDOT:PSS layer $(\sim 20 \mathrm{~nm})$ was coated and dried at $150{ }^{\circ} \mathrm{C}$ for 20 minutes. The mixture of PM6 and acceptor in a fixed weight ratio was dissolved in chloroform with a donor concentration of $7 \mathrm{mg} / \mathrm{mL}$. Different ratios of DIO (1,8-diiodooctane) or CN (1chloronaphthalene) were added to the solution by 30 minutes before device fabrication. The blend solution were spin-coated on the top of PEDOT:PSS layer followed by a thermal annealing step $\left(100^{\circ} \mathrm{C}-10 \mathrm{~min}\right)$. The optimal thickness of the binary and ternary BHJ film was about $100 \mathrm{~nm}$. Atop the active layer, the electron transport layer of PDINO was spin-coated. The concentration was 1 $\mathrm{mg} / \mathrm{mL}$. The optimal spin speed was $3000 \mathrm{rpm}$. Finally, Al (ca. $90 \mathrm{~nm}$ ) was thermally deposited. The $J-V$ measurements were performed in a nitrogen atmosphere filling glove box and were conducted on a computer-controlled Keithley 2400 source measure unit. The device active area was of $0.04 \mathrm{~cm}^{2}$. An AM 1.5G simulated solar illumination (AAA grade, XES-70S1) was used as the light source. The illumination intensity in front of the cell sample was calibrated to be $100 \mathrm{~mW} / \mathrm{cm}^{2}$ with a reference silicon cell. The EQE measurements were performed with the as-fabricated solar cell using a QE-R3011 instrument (Enli Technology Co. Ltd., Taiwan). 


\subsection{Measurements of the hole and electron mobility by the space-charge limited current (SCLC) method}

The hole-only devices were fabricated with a configuration of ITO/PEDOT:PSS/blend/Au. The electron-only devices were fabricated with a configuration of ITO/titanium (diisopropoxide) bis(2,4-pentanedionate) (TIPD)/blend/CBL/Al. The TIPD buffer layer was prepared by spin-coating a $3.5 \mathrm{wt} \%$ TIPD isopropanol solution onto the pre-cleaned ITO substrate and then baked at $150{ }^{\circ} \mathrm{C}$ for 10 min to convert TIPD into TOPD. ${ }^{1}$ Subsequently, the blend was spin-coated on it under the same condition as preparation of the optimal solar cell. The Au or Al layer was thermally deposited on the top of the blend in vacuum. The Au layer was deposited under a low speed $(1 \AA / 10 \mathrm{~s})$ to avoid the penetration of $\mathrm{Au}$ atoms into the active layer. The Al layer was deposited at a speed of 1 $\AA /$ s. The hole and electron mobility was extracted by fitting the current density-voltage curves using the Mott-Gurney law

$J_{\mathrm{SCL}}=9 \varepsilon \varepsilon_{0} \mu V^{2} /\left(8 L^{3}\right)$

where $\varepsilon$ is the dielectric constant of the organic component, $\varepsilon_{0}$ is the permittivity of the vacuum (8.85419 $\left.\times 10^{-12} \mathrm{CV}^{-1} \mathrm{~m}^{-1}\right), \mu$ is the zero-field mobility, $J$ is the current density, $L$ is the thickness of the active layer, and $V=V_{\text {app }}-V_{\text {bi }}$, here $V_{\text {app }}$ is the applied potential, and $V_{\text {bi }}$ the built-in potential which results from the difference in the work function values of the anode and the cathode (in the hole-only device, $V_{\mathrm{bi}}=0.2 \mathrm{~V}$, and in the electron-only device, $V_{b i}=0.4 \mathrm{~V}$ ). The hole and electron mobility of the solar cell blend are deduced from the intercept value of $9 \varepsilon_{0} \mu /\left(8 L^{3}\right)$ by linearly plotting $\ln (J)$ vs. $\ln (V)$ (the slope of $\ln (J)$ vs. $\ln (V)$ is $\approx 2$ ).

\subsection{Transient absorption spectroscopy}

A femtosecond laser system (Pharos, Light Conversion) delivered laser pulses at $1030 \mathrm{~nm}$ (180 fs, 6 $\mathrm{kHz}$ ), which were then divided into two components by using a 9:1 beam splitter. The major component was sent to an optical parametric amplifier (Orpheus, Light Conversion) to generate the pump pulses $(840 \mathrm{~nm}, 6 \mathrm{kHz})$. The minor component was further attenuated and focused into a 3$\mathrm{mm}$ sapphire plate to generate the probe pulses. Both the pump and probe pulses were guided into a Harppia spectrometer and time resolved spectral data were recorded. A short-pass filter was inserted into the probe beam to cut off the fundamental light of $1030 \mathrm{~nm}$. The time delay between the pump and probe beams were regulated through a computer-controlled motorized translation stage in the probe beam. The temporal resolution between the pump and the probe pulses was determined to be 200 fs (FWHM). The transmitted light was detected by a CMOS linear image sensor. The excitation pulsed energy was $\sim 60 \mathrm{~nJ} /$ pulse as measured at the sample site. The stability of the samples was spectrophotometrically checked before and after each experiment. Analysis of the kinetic traces derived from time-resolved spectra was performed using nonlinear least-square fitting 
to a general sum-of-exponentials function after deconvolution of instrument response function (IRF). All the spectroscopic measurements were carried out at room temperature.

\subsection{Incident light-power dependent measurements of $J-V$ characteristics}

The recombination mechanisms were studied by measuring the light intensity dependent $J-V$ characteristics. Experimentally, the light from a AAA-grade AM 1.5G light source was allowed to pass a series of neutral density filters (metallic UV-VIS-NIR, Andover) and the incident light power was controlled from $100 \mathrm{~mW} / \mathrm{cm}^{2}$ to $1 \mathrm{~mW} / \mathrm{cm}^{2}$. At short-circuit, the involvement of the bimolecular recombination can be reflected by the $\alpha$ value estimated from the logarithm plot between $J_{\text {sc }}$ and light intensity $(P)$ following Eq. $J_{\text {sc }} \propto P^{\alpha}$. At open-circuit, the including of the monomolecular mechanism can be reflected by the $n$ value according to Eq. $V_{\text {oc }} \propto(\mathrm{n} k T / q) \ln P$, here $k, T$, and $q$ are the Boltzmann constant, temperature in Kelvin, and the elementary charge, respectively. $^{23}$

\subsection{GIWAXS measurements.}

GIWAXS data was carried out with a Xeuss 2.0 SAXS/WAXS laboratory beamline using a $\mathrm{Cu}$ Xray source $\left(8.05 \mathrm{keV}, 1.54 \AA\right.$ ) and Pilatus $3 \mathrm{R} 300 \mathrm{~K}$ detector. The incidence angle is $0.2^{\circ}$.

\subsection{GISAXS characterization.}

GISAXS was conducted at 19U2 SAXS beamline at Shanghai Synchrotron Radiation Facility, Shanghai, China, using the $0.15^{\circ}$ incident angle with $10 \mathrm{keV}$ primary beam.

\subsection{Cyclic voltammetry measurements.}

For $\mathrm{CV}$ experiments, the compound was fully dissolved in $\mathrm{N}_{2}$-degassed anhydrous $\mathrm{CHCl}_{3}$ with a concentration of $10^{-4} \mathrm{M}$ and then the solution was deposited onto the work electrode surface to form a thin solid film. CV traces were measured on an electrochemical workstation (CHI 660) at a scan rate of $50 \mathrm{mV} / \mathrm{s}$ using tetrabutylammonium tetrafluoroborate $\left(\mathrm{Bu}_{4} \mathrm{NBF}_{4}\right)$ as the supporting electrolyte. A glassy carbon electrode, a $\mathrm{Pt}$ wire and an $\mathrm{Ag} / \mathrm{AgCl}$ electrode were used as the working, counter and reference electrodes, respectively. 


\section{Organic synthesis}

Synthesis of compound 2:

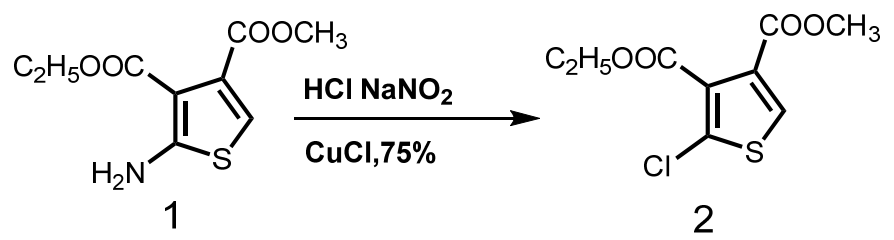

Compound $1(1.5 \mathrm{~g}, 0.436 \mathrm{mmol})$ in aqueous $2 \mathrm{M} \mathrm{HCl}(80 \mathrm{~mL})$ was stirred at room temperature for 20 minutes. The solution was cooled to $0{ }^{\circ} \mathrm{C}$ and $\mathrm{NaNO}_{2}(605 \mathrm{mg}, 8.72 \mathrm{mmol})$ was added. The mixture was stirred for 10 minutes. $\mathrm{CuCl}(1.1 \mathrm{~g}, 10.9 \mathrm{mmol})$ was then added in small portions. The solution was allowed to react for 45 minutes. Dichloromethane $(4 \times 20 \mathrm{~mL})$ was then extracted and washed with saturated sodium bisulfite aqueous solution $(5 \times 20 \mathrm{~mL})$ and water $(3 \times 20 \mathrm{~mL})$. The combined organic layers were dried with solid $\mathrm{Na}_{2} \mathrm{SO}_{4}$ and the organic solvent was removed. The crude product was purified with a chromatograph on silica gel eluting with dichloromethane as the eluent (1 g, 75\%). ${ }^{1} \mathrm{H}-\mathrm{NMR}\left(400 \mathrm{MHz}, \mathrm{CDCl}_{3}\right): \delta 7.81(\mathrm{~s}, 1 \mathrm{H}), 4.38-4.31(\mathrm{~m}, 2 \mathrm{H}), 3.80(\mathrm{~s}, 3 \mathrm{H})$, 1.35-1.30 (m, 3H). ${ }^{13} \mathrm{C}$ NMR (400 MHz, $\left.\mathrm{CDCl}_{3}\right): \delta 163.08,161.24,132.09,131.62,131.38,130.27$, 62.16, 52.55, 14.07. MS (MALDI-TOF): calculated for $\mathrm{C}_{9} \mathrm{H}_{9} \mathrm{ClO}_{4} \mathrm{~S}: 248.68$; found: 248.20.

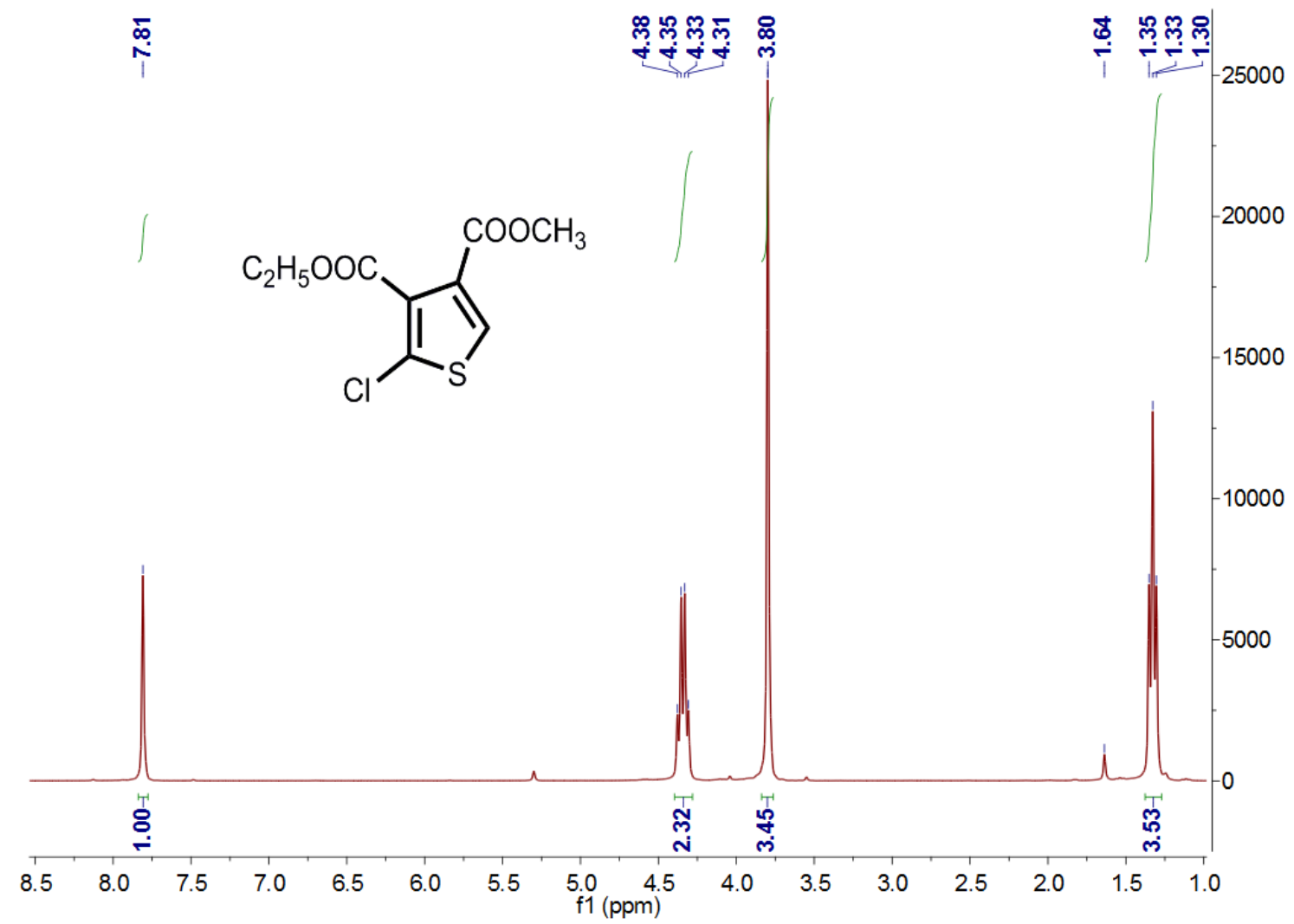

${ }^{1} \mathrm{H}$ NMR spectrum of compound 2 


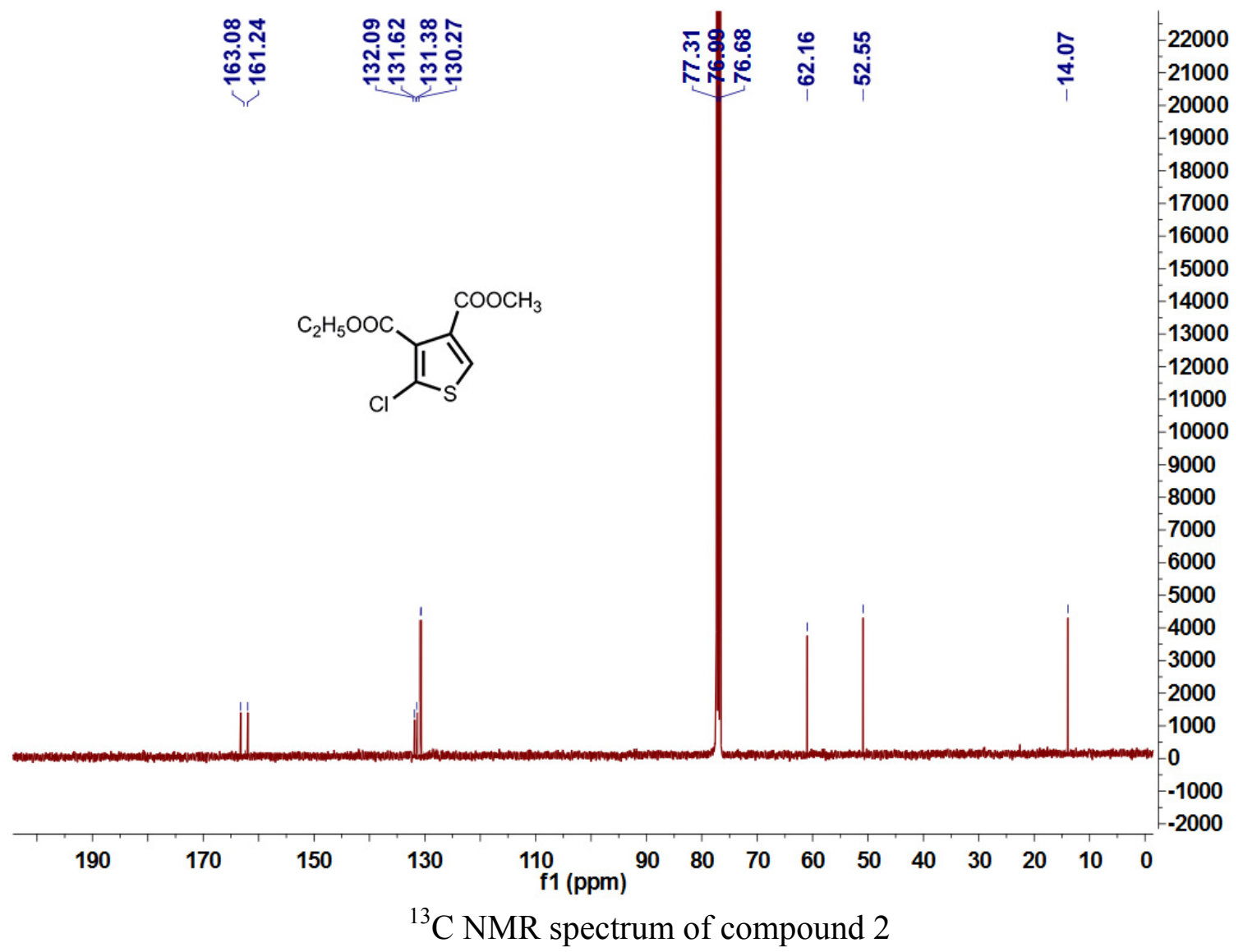

Synthesis of compound 3:

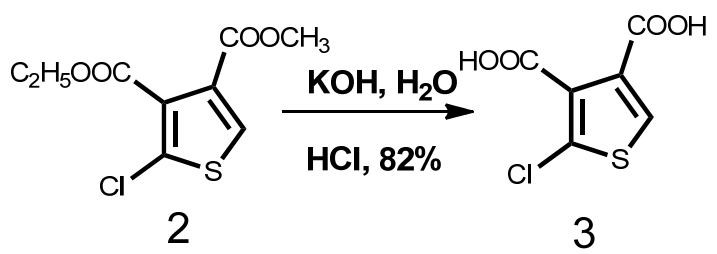

Compound 2 ( $1 \mathrm{~g}, 4.03 \mathrm{mmol})$ and $\mathrm{KOH}(1.4 \mathrm{~g}, 25 \mathrm{mmol})$ was dispersed/dissolved in $40 \mathrm{ml} \mathrm{of} \mathrm{H}_{2} \mathrm{O}$ and then stirred under reflux for 12 hours in a one-neck flask. After reaction and cool down to room temperature, the solution was extracted with diethyl ether $(4 \times 100 \mathrm{~mL})$. The combined organic layers were dried over solid $\mathrm{Na}_{2} \mathrm{SO}_{4}$ and the organic solvent was obtained to give a white solid (compound 3, $675 \mathrm{mg}, 82 \%$ ). ${ }^{1} \mathrm{H}-\mathrm{NMR}\left(400 \mathrm{MHz}, \mathrm{CDCl}_{3}\right.$ ): $\delta 8.13$ (s, 1H), 3.45-3.39 (m, 2H). MS (MALDI-TOF): calculated for $\mathrm{C}_{6} \mathrm{H}_{3} \mathrm{ClO}_{4} \mathrm{~S}$ : 206.60; found: 206.00 . 


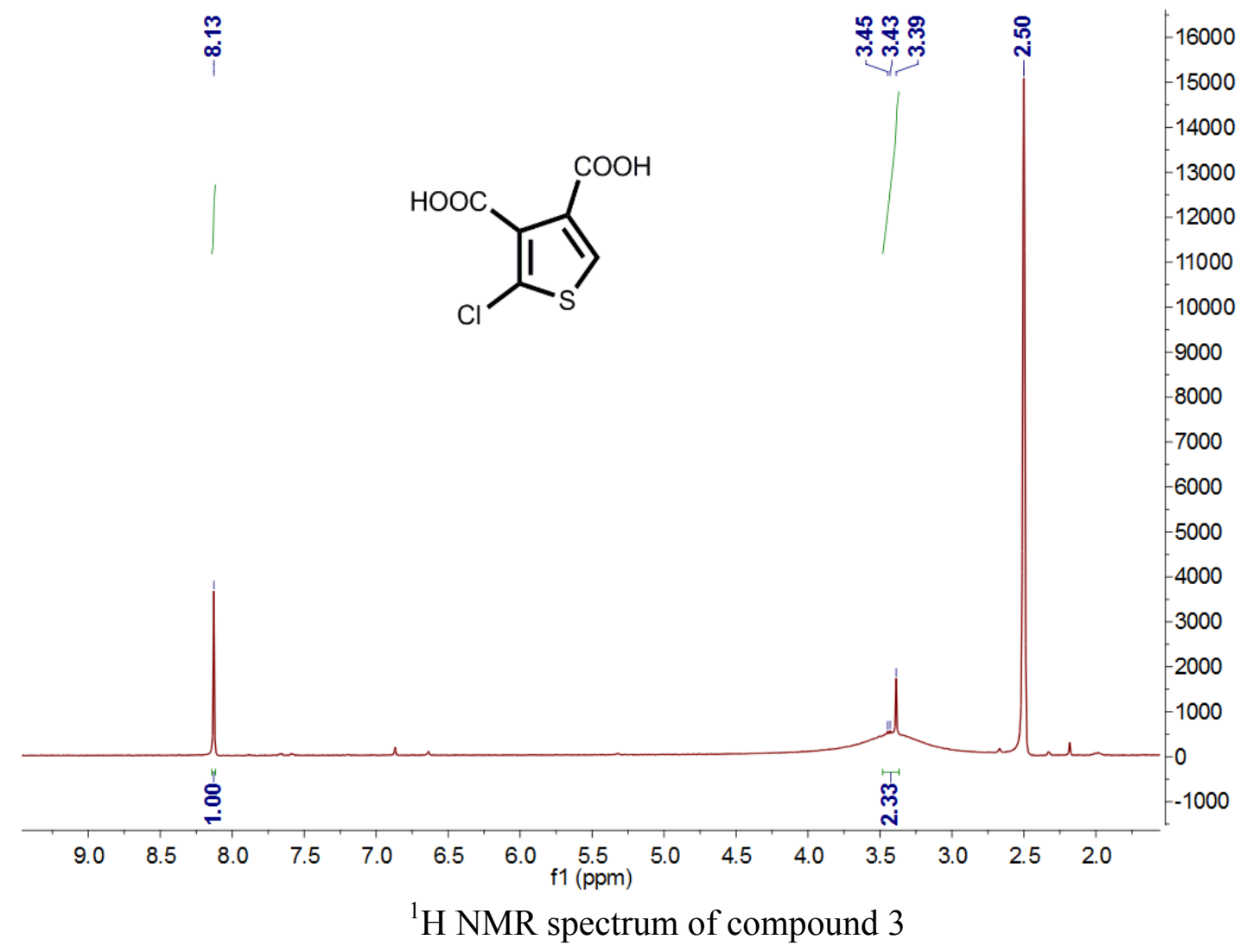

Synthesis of Compound 4:<smiles>O=C(O)c1csc(Cl)c1C(=O)O</smiles>

3

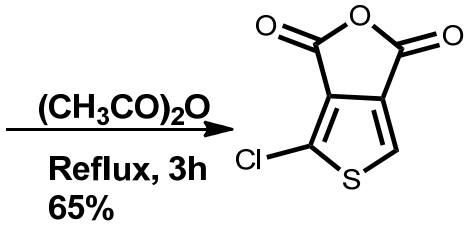

4

Compound 3 (675 mg, $3.28 \mathrm{mmol}$ ) was dissolved in acetic anhydride, and the reaction mixture was stirred at $140{ }^{\circ} \mathrm{C}$ for 3 hours. The reaction mixture was then cooled to room temperature and extracted with $\mathrm{CHCl}_{3}$ and washed twice with water. The organic layer was dried over solid $\mathrm{Na}_{2} \mathrm{SO}_{4}$. Compound 4 was purified with a chromatograph on silica gel using $\mathrm{CH}_{2} \mathrm{Cl}_{2}$ as the eluent (400 $\mathrm{mg}$, 65\%). ${ }^{1} \mathrm{H}-\mathrm{NMR}$ (400 MHz, $\mathrm{CDCl}_{3}$ ): $\delta 7.88$ (s, $\left.1 \mathrm{H}\right) .{ }^{13} \mathrm{C} \mathrm{NMR}\left(400 \mathrm{MHz}, \mathrm{CD}_{2} \mathrm{Cl}_{2}\right.$ ): $\delta$ 155.26, 154.85, 135.32, 133.79, 130.09, 127.76. MS (MALDI-TOF): calculated for $\mathrm{C}_{6} \mathrm{HClO}_{3} \mathrm{~S}$ : 188.58 ; found: 188.20 . 


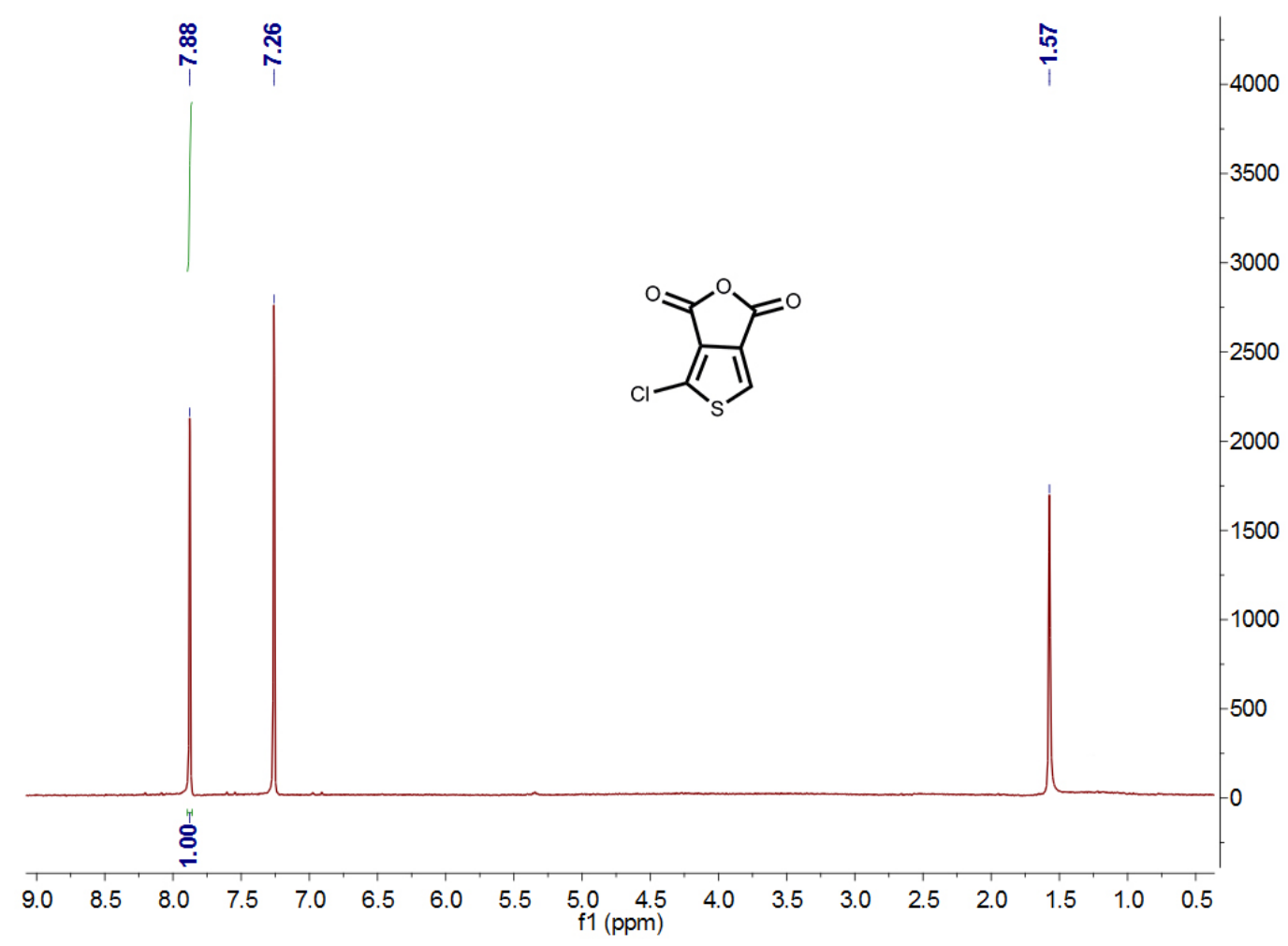

${ }^{1}$ H NMR spectrum of_Compound 4

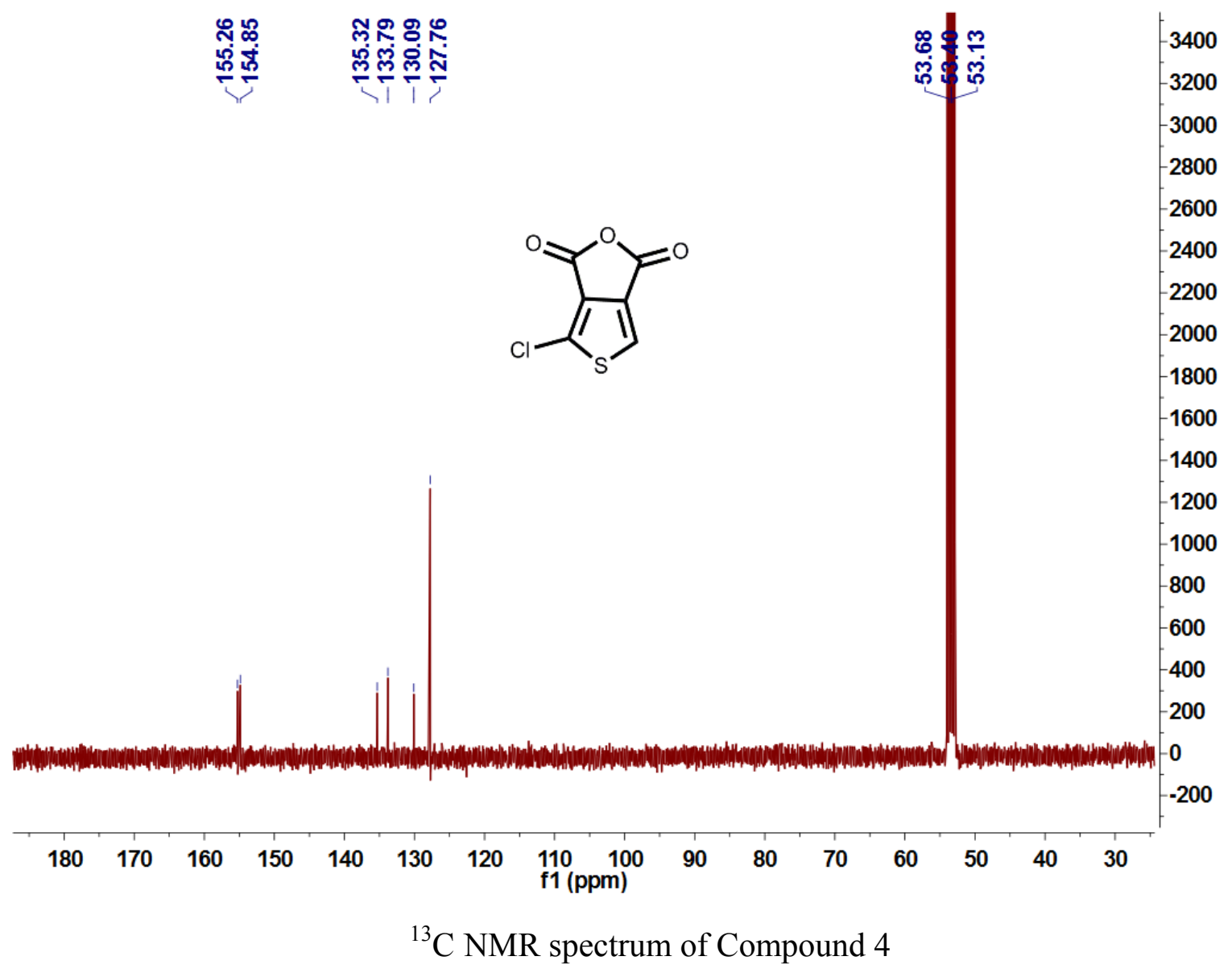


Synthesis of Compound 5:
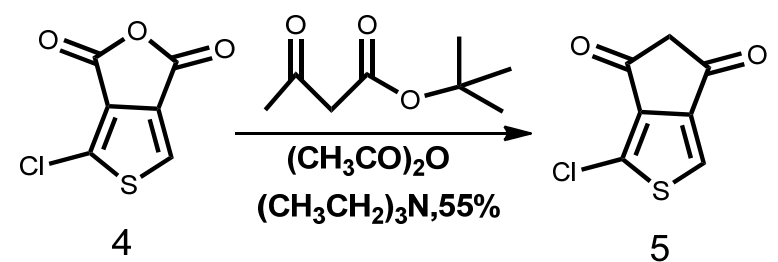

Compound $4(750 \mathrm{mg})$ was dissolved in acetic anhydride $(6 \mathrm{~mL})$. Triethylamine $(6 \mathrm{~mL})$ and ethyl acetate $(0.6 \mathrm{~mL})$ were added and the mixture was stirred at $65^{\circ} \mathrm{C}$ for overnight. The reaction mixture was poured on the mixtue of ice and $\mathrm{HCl}$. The oil-like product was extracted and dried with solid $\mathrm{Na}_{2} \mathrm{SO}_{4}$. The solvent was removed. The resulting carboxylic acid is treated with concentrated hydrochloric acid. The mixture was refluxed for $10 \mathrm{~min}$ and then cooled down to $\mathrm{rt}$ and extracted with $\mathrm{CH}_{2} \mathrm{CI}_{2}$. The combined organic extracts were dried $\left(\mathrm{Na}_{2} \mathrm{SO}_{4}\right)$ and the orgaic solvent was removed. The crude product was suspended in a minimum amount of diethyl ether and stirred at room temperature for 1 hour, and Compound 5 was obtained thorugh filtration $(415 \mathrm{mg}, 55 \%)$. ${ }^{1} \mathrm{H}$ NMR (400 MHz, $\left.\mathrm{CDCl}_{3}\right): \delta 8.05(\mathrm{~s}, 1 \mathrm{H}), 3.50$ (s, 2H). MS (MALDI-TOF): calculated for $\mathrm{C}_{7} \mathrm{H}_{3} \mathrm{ClO}_{2} \mathrm{~S}$ : 186.61 ; found: 185.78 .

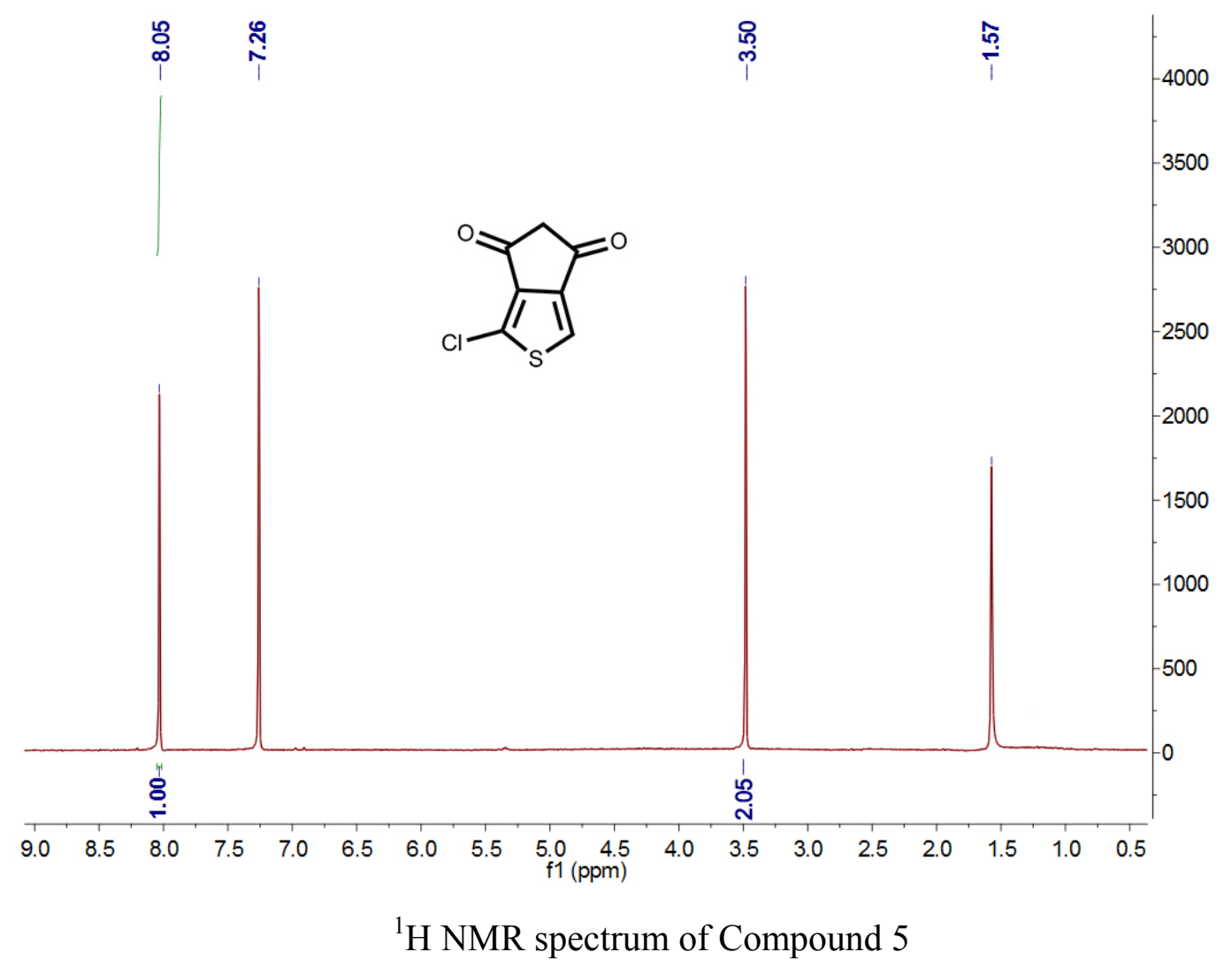


Synthesis of CT-Cl:

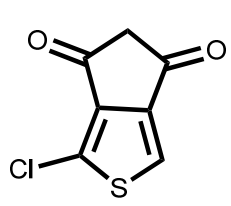

5

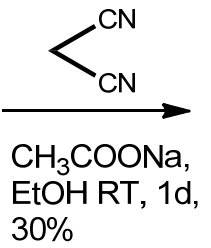

$30 \%$

Compound 5 (283 mg, $1.52 \mathrm{mmol}$ ) and malononitrile (91 mg, $1.366 \mathrm{mmol}$ ) was dissolved in $10 \mathrm{ml}$ of dried ethanol; then anhydrous sodium acetate $(250 \mathrm{mg}, 3.04 \mathrm{mmol})$ was added under stirring. After keeping for overnight, the reaction mixture was poured into water and acidified to $\mathrm{pH} 1-2$ with hydrochloric acid. The mixture was then extracted three times with $\mathrm{CHCl}_{3}$ and the organic layer was washed twice with water and dried over solid $\mathrm{Na}_{2} \mathrm{SO}_{4}$. The crude product was purified with a chromatograph on silica gel using $\mathrm{CH}_{2} \mathrm{Cl}_{2}$ as th eluent to afford purified product CT-Cl (100 mg, 30\%). ${ }^{1} \mathrm{H}-\mathrm{NMR}\left(400 \mathrm{MHz}, \mathrm{CDCl}_{3}\right): \delta 8.21(\mathrm{~s}, 1 \mathrm{H}), 3.95(\mathrm{~s}, 2 \mathrm{H}) .{ }^{13} \mathrm{C} \mathrm{NMR}\left(400 \mathrm{MHz}, \mathrm{CD}_{2} \mathrm{Cl}_{2}\right)$ : $\delta 185.08,159.28,143.85,139.01,133.26,126.98,112.23,111.52,79.01,49.28$. MS(MALDI-TOF): calculated for $\mathrm{C}_{10} \mathrm{H}_{3} \mathrm{ClN}_{2} \mathrm{OS}$ : 234.66; found: 234.12 .

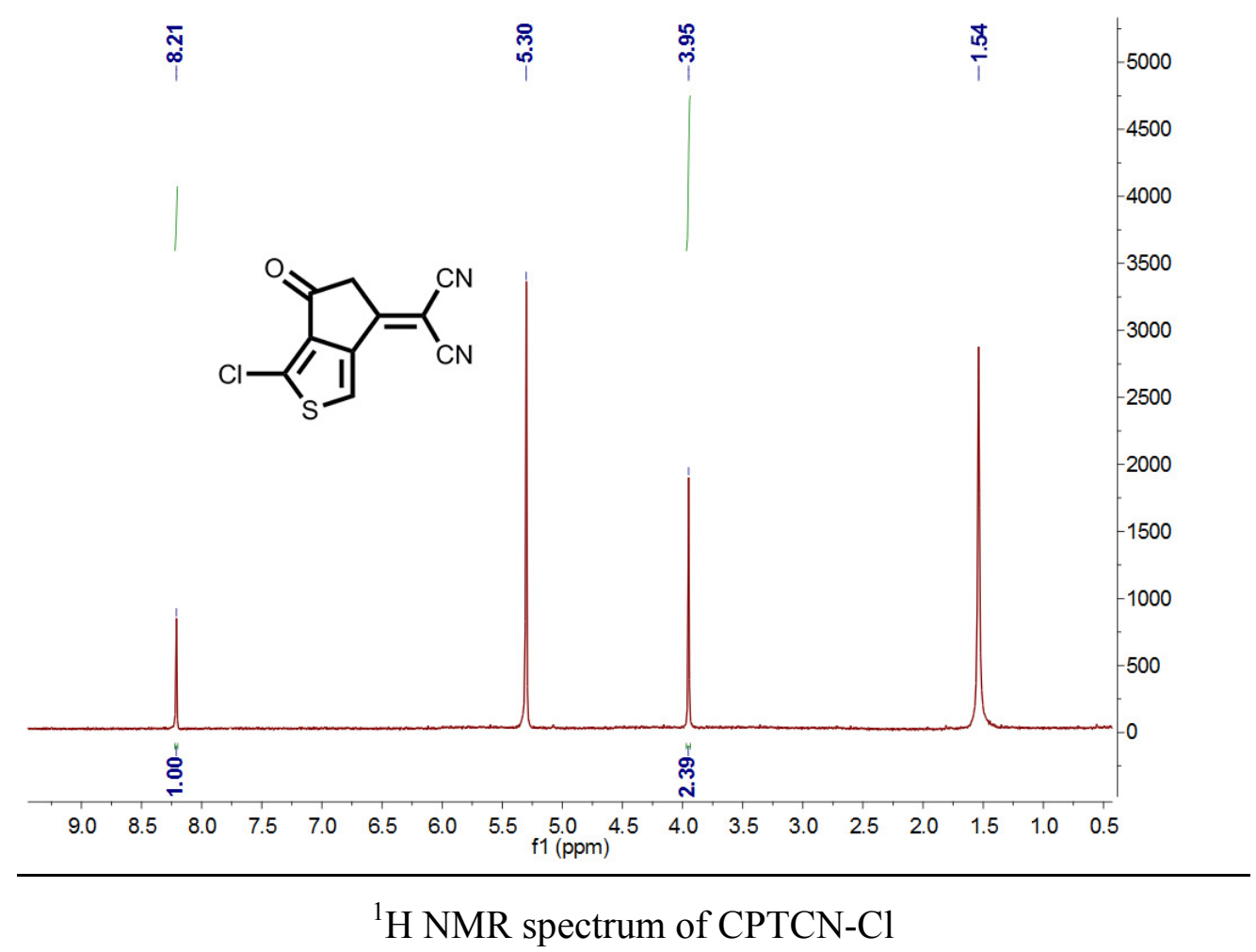




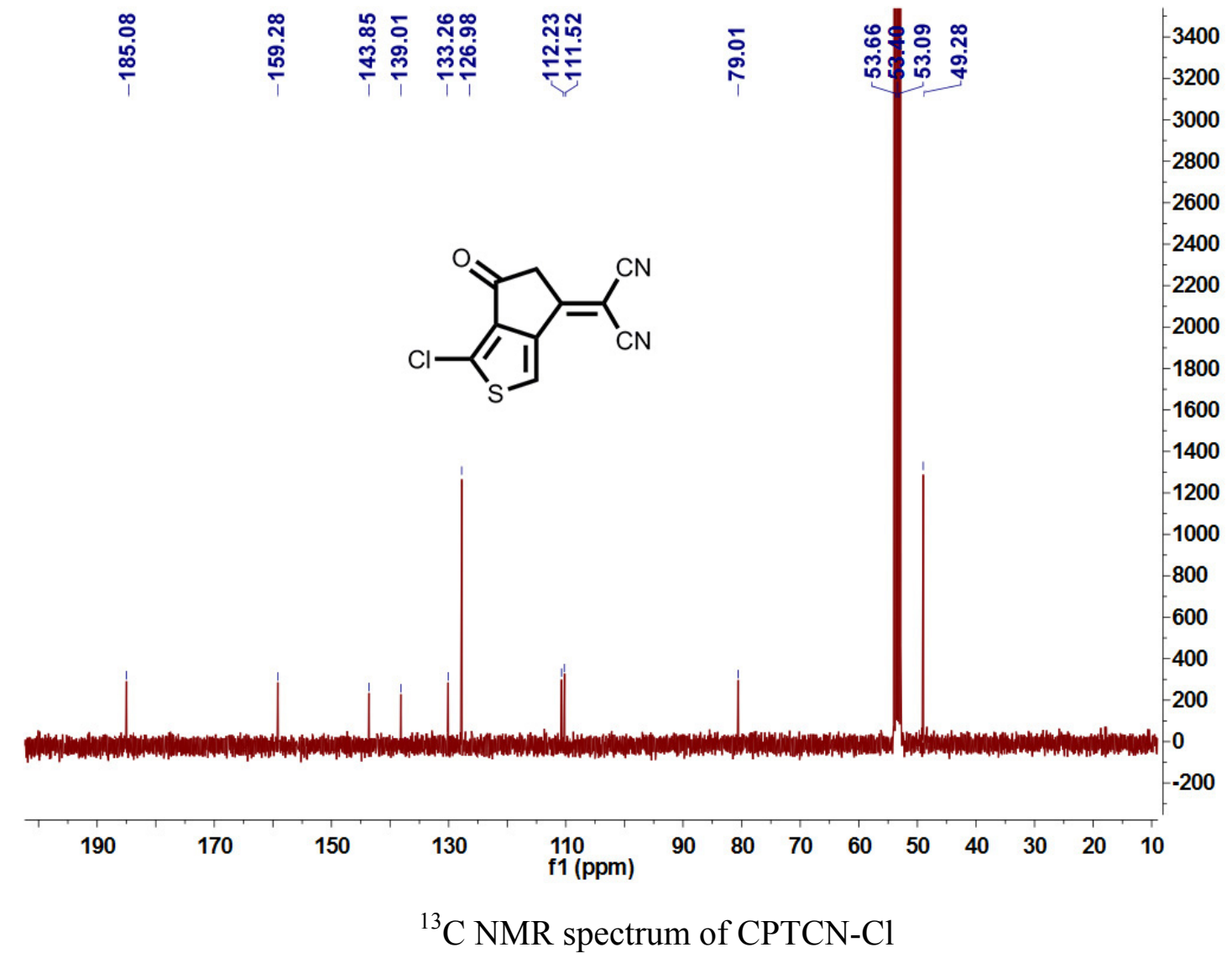

Synthesis of Compound BTCT-2Cl:

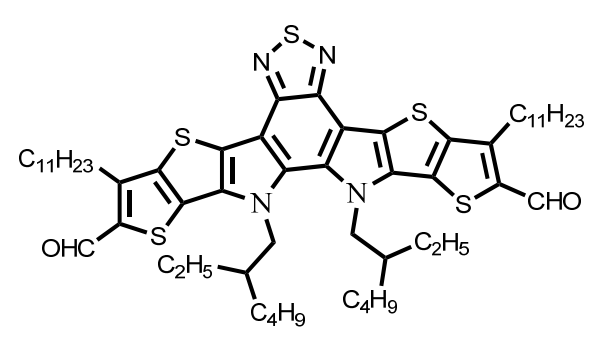

BTTT-2CHO

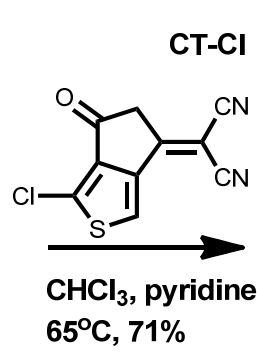

$65^{\circ} \mathrm{C}, 71 \%$

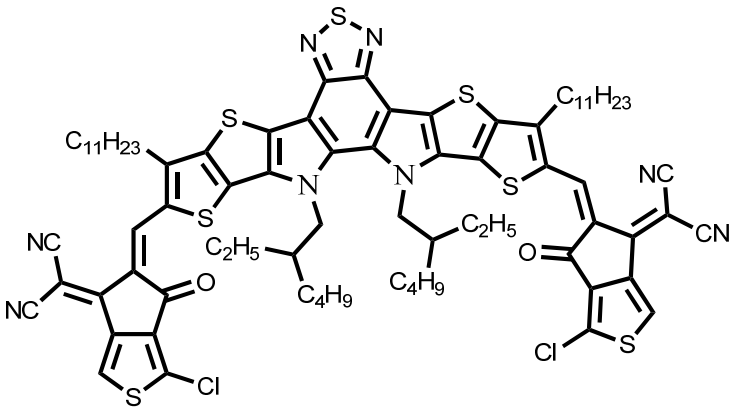

BTCT-2Cl

BTTT-2CHO (20 mg, $0.02 \mathrm{mmol})$, CT-Cl (20 mg, $0.085 \mathrm{mmol})$, chloroform (6 mL) and pyridine $(0.3 \mathrm{~mL})$ were added to a two-neck round bottom flask. The mixture was deoxygenated with nitrogen for 30 minutes and then refluxed for 24 hours. After cooling down to room temperature, the mixture was poured into $\mathrm{MeOH}(15 \mathrm{~mL})$ and the solid was obtained through filtration. The solid was purified with a chromatograph on silica gel using petroleum ether / dichloromethane (1:2) as the eluent to give a dark blue solid. (20 mg, 71\%). ${ }^{1} \mathrm{H}-\mathrm{NMR}\left(400 \mathrm{MHz}, \mathrm{CDCl}_{3}\right): \delta 9.09(\mathrm{~s}, 2 \mathrm{H})$, $8.19(\mathrm{~s}, 2 \mathrm{H}), 4.75(\mathrm{~m}, 4 \mathrm{H}), 3.23(\mathrm{~m}, 4 \mathrm{H}), 2.07$ (m, 4H), 1.88-1.50 (m, 8H), 1.31-1.19 (m, 42H), 1.01 $(\mathrm{m}, 6 \mathrm{H}), 0.88-0.87(\mathrm{~m}, 6 \mathrm{H}) .{ }^{13} \mathrm{C} \mathrm{NMR}\left(400 \mathrm{MHz}, \mathrm{CDCl}_{3}\right): \delta 187.15,177.70,157.01,145.72$, $143.50,140.00,139.55,139.17,130.07,129.85,129.77,129.30,127.75,126.60,123.66,121.22$, 
$118.25,103.49,69.64,60.25,37.56,32.70,31.32,29.32,28.58,27.89,25.54,24.37,23.77,18.05$, 11.00. MS(MALDI-TOF): calculated for $\mathrm{C}_{78} \mathrm{H}_{84} \mathrm{Cl}_{2} \mathrm{~N}_{8} \mathrm{O}_{2} \mathrm{~S}_{7}$ : 1460.90; found: 1460.50 .

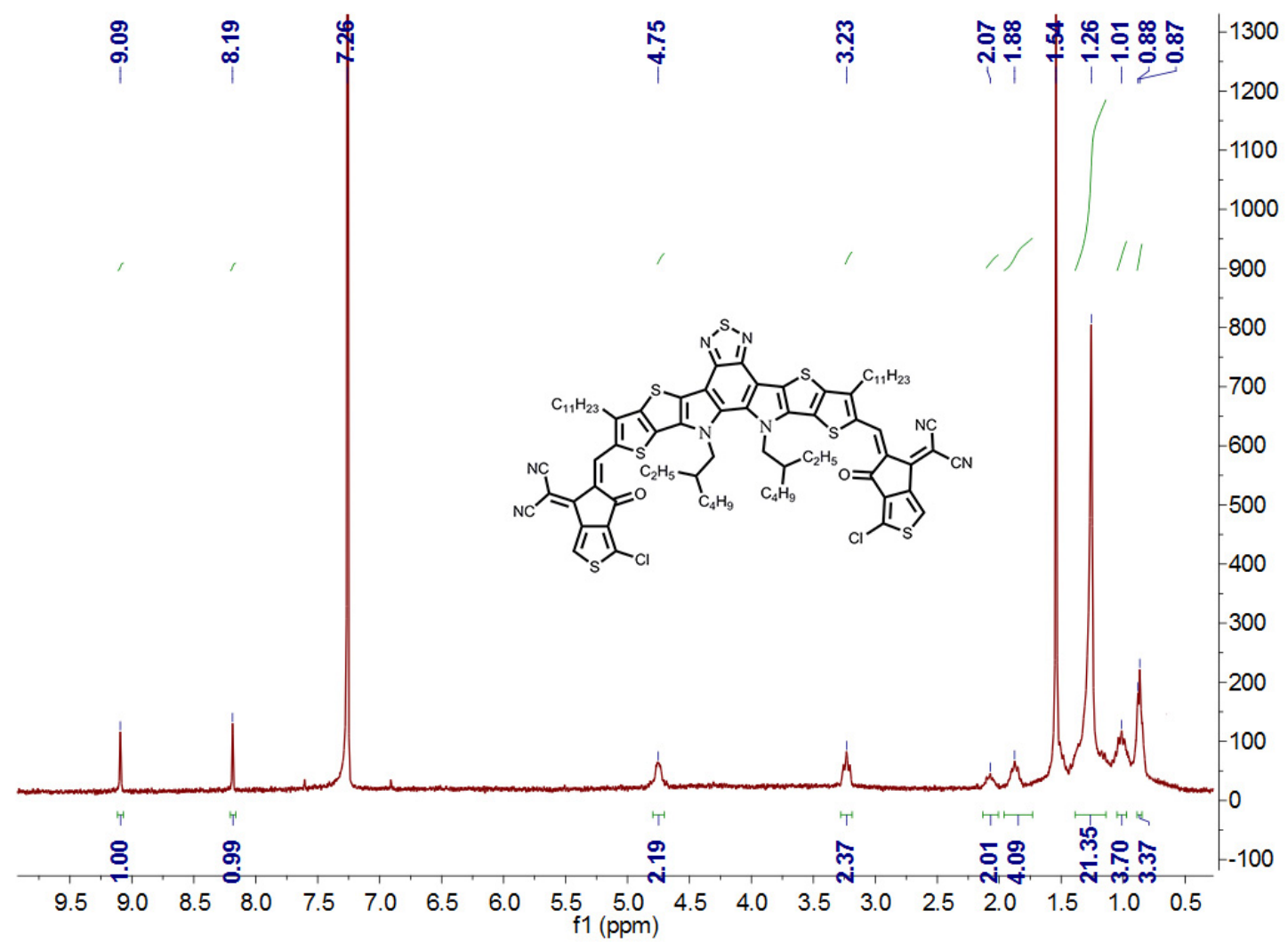

${ }^{1} \mathrm{H}$ NMR spectra of BTCT-Cl

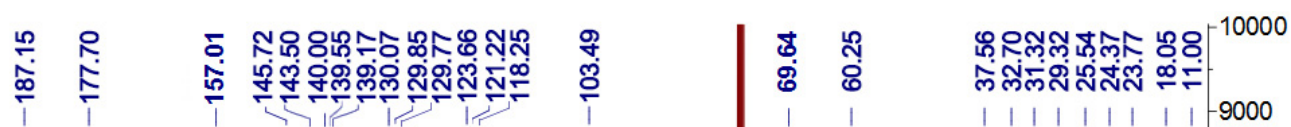

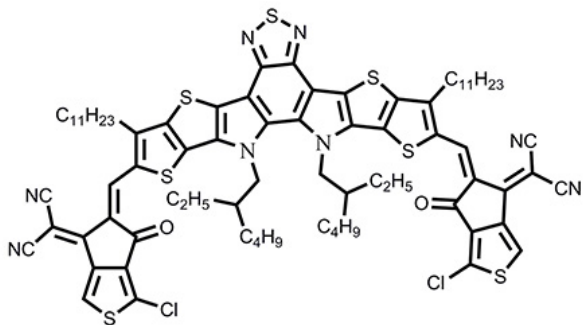

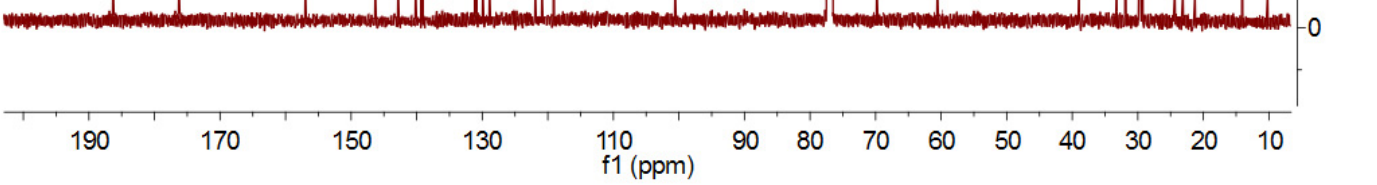

${ }^{13} \mathrm{C}$ NMR spectra of BTCT-2Cl 
MALDI-TOF,CCA,1,20190711

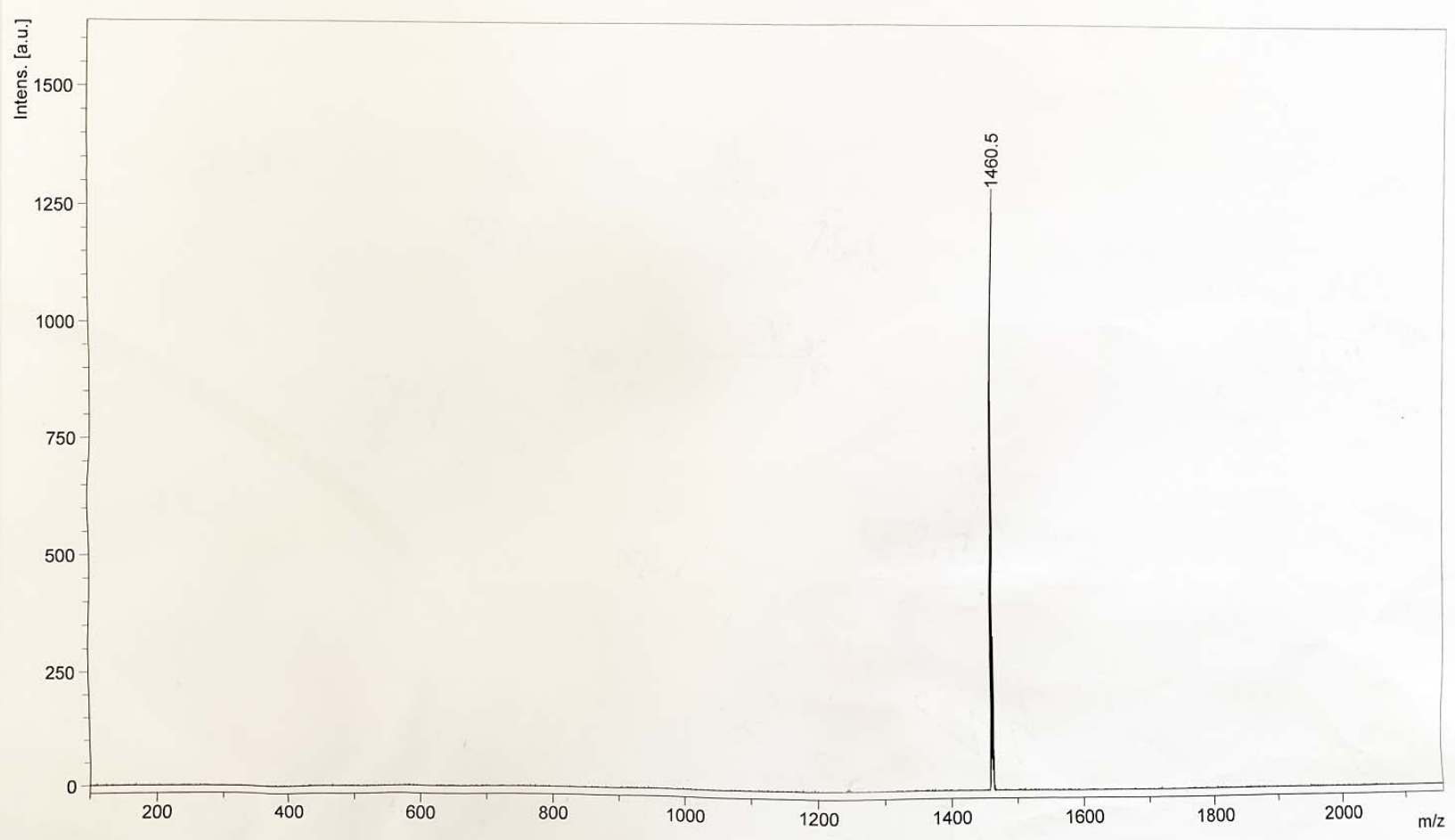

The MALDI-TOF spectra of BTCT-2Cl 


\section{Supporting Figures}

Figure S1. The solution UV-vis absorption spectra of BTCT-2Cl and Y6 in chloroform.

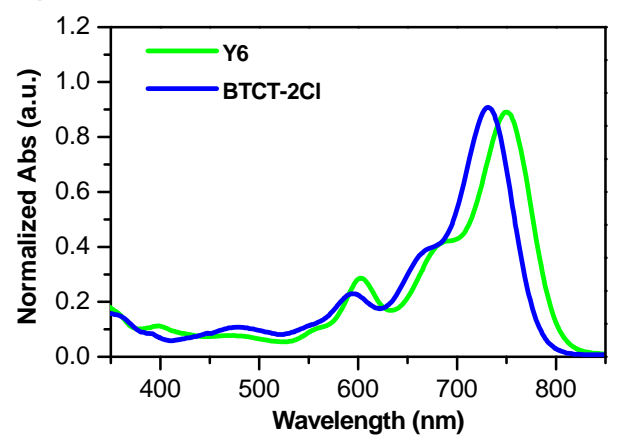

Figure S2. (a and b) Cyclic voltammetry (CV) traces of the Y6 (a) and BTCT-2Cl (b).
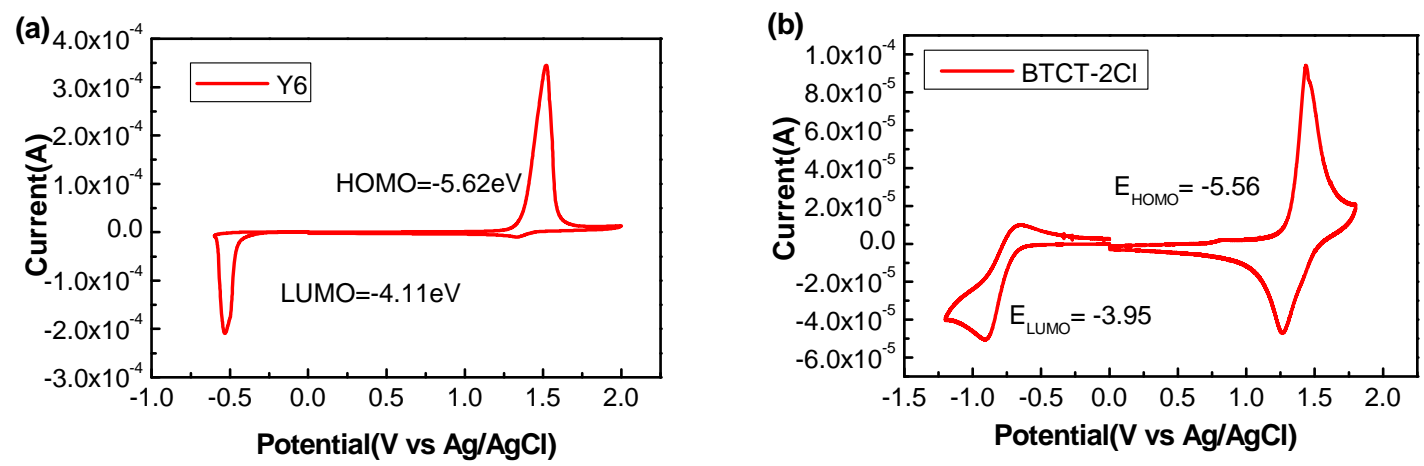

Figure S3. Film absorption spectra (a) and energy levels diagram (b) of PM6, BTCT-2CI, IT-4F, $\mathrm{PC}_{71} \mathrm{BM}$, and $\mathrm{Y} 6$.
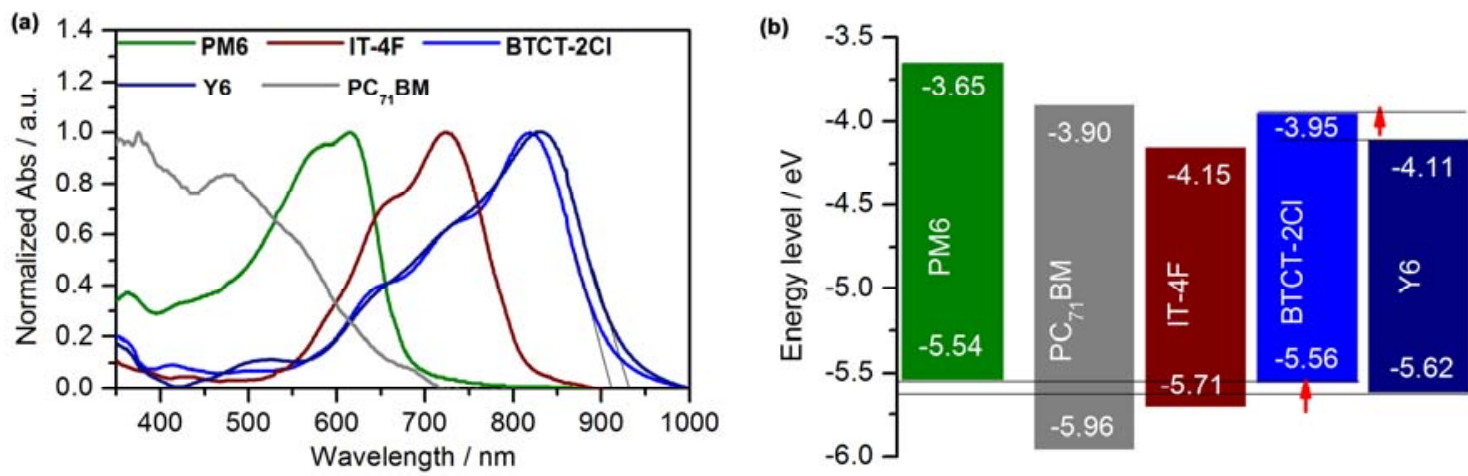
Figure S4. fs-TA spectra and representative kinetic curves of pristine BTCT-2Cl film (a and b) and PM6: BTCT-2Cl without the use of DIO (c and d) upon excitation at $840 \mathrm{~nm}$. The new emerging 630-nm GSB signal is caused by hole transfer from BTCT-2Cl to PM6.

(a)
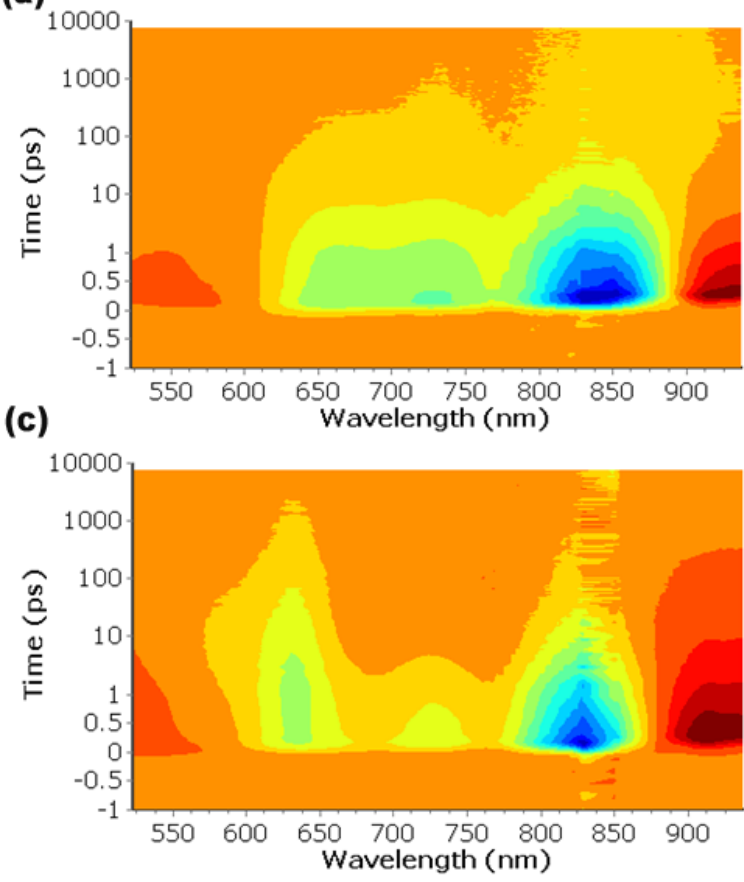

(b)

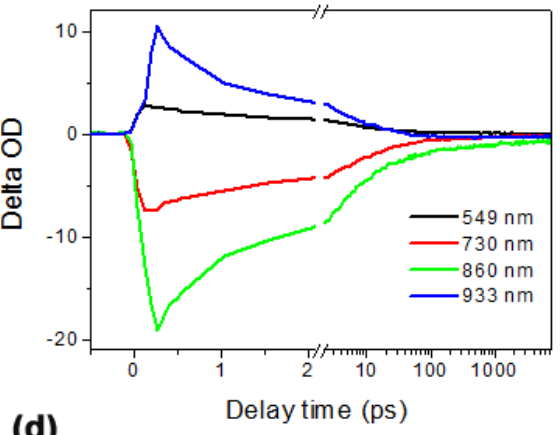

(d)

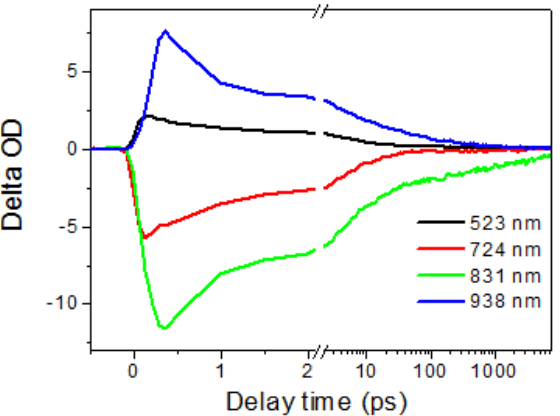

Figure S5. fs-TA spectra of the IT-4F ternary blend film upon excitation at $840 \mathrm{~nm}$.

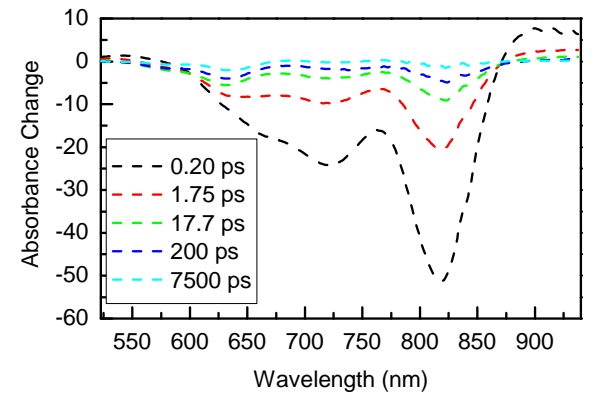


Figure S6. The fitting of GIWAXS peaks. (Left column) The $\pi-\pi$ peaks are fitted from the OOP profile while (right column) the lamellar peaks are fitted from the IP profile. The blend films have two components in the fitting, the $\pi-\pi$ peak is identified from the one with higher $q$ value.

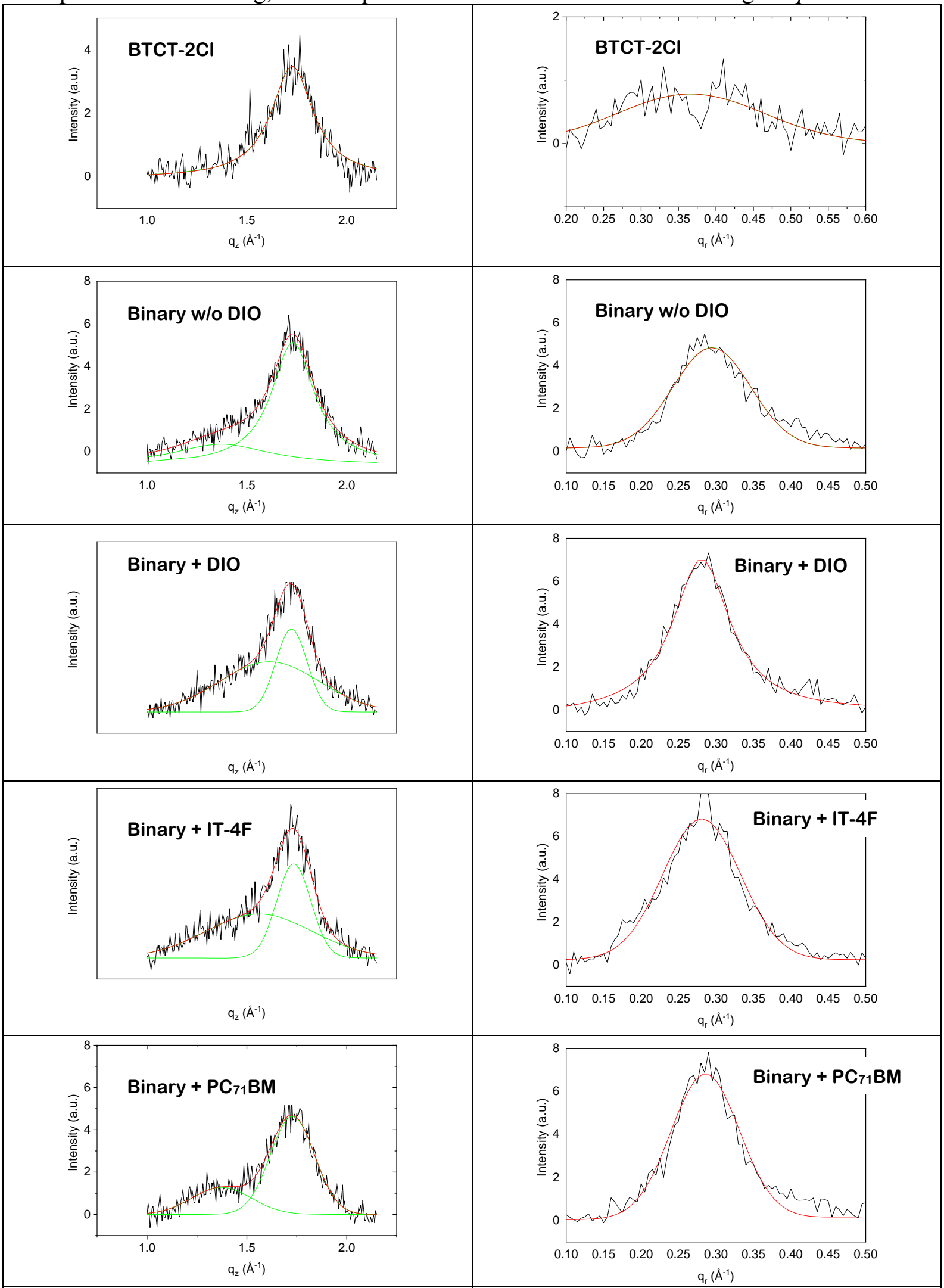


Figure S7. The $J^{0.5}-V$ plots for calculations of the electron (a) and hole (b) mobilities of the BTCT-2CI based binary and ternary solar cell blends using the space-charge-limited current (SCLC) method.

(a) 100

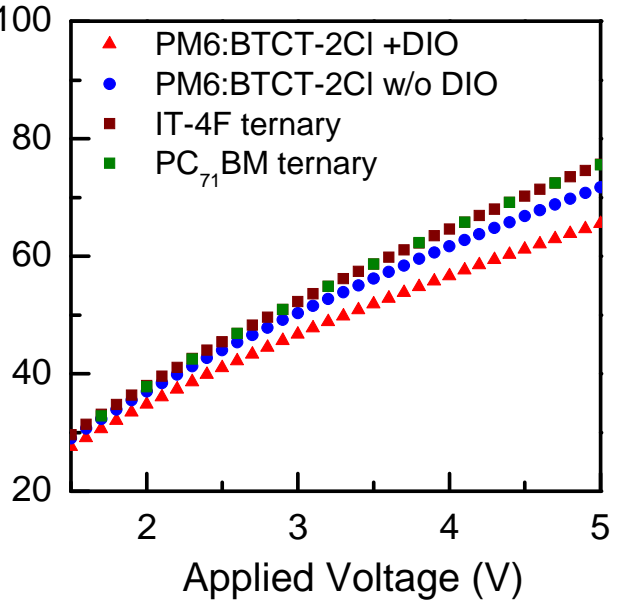

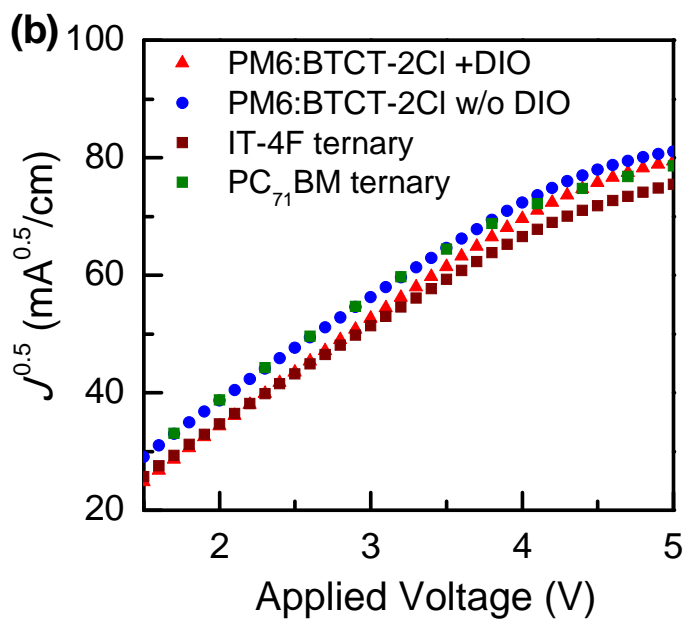

Figure S8. The 2D GISAXS patterns (a-d) and the corresponding horizontal linecuts with fitting (e and $\mathrm{f}$ ).
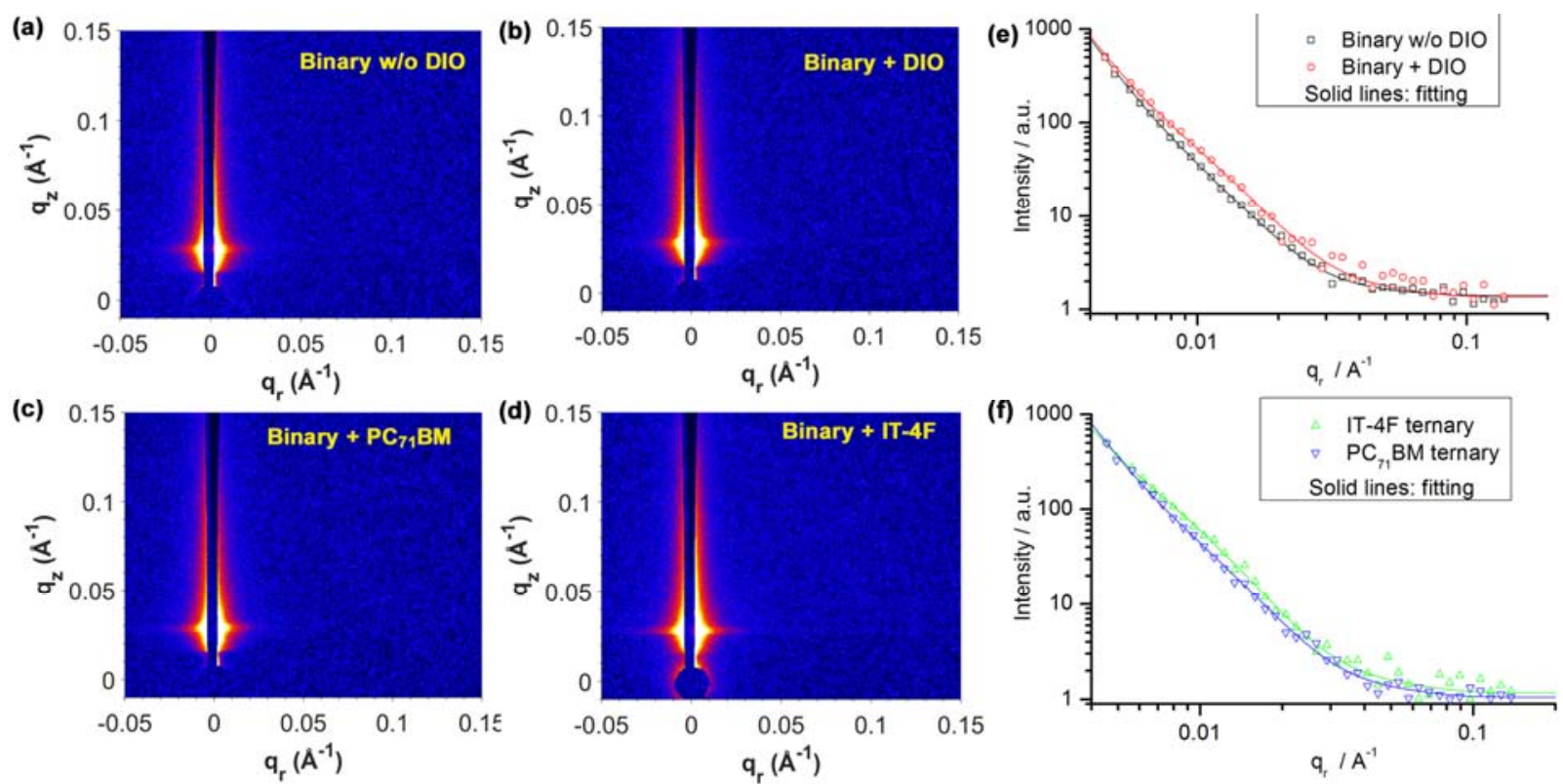
Figure S9. Magnified TEM (a) and $1 \mu \mathrm{m} \times 1 \mu \mathrm{m}$ scaled AFM height (b) and phase (c) images of the BTCT-2Cl binary (without and with the use of 5\% DIO), the IT-4F and $\mathrm{PC}_{71} \mathrm{BM}$ ternary blends, respectively.
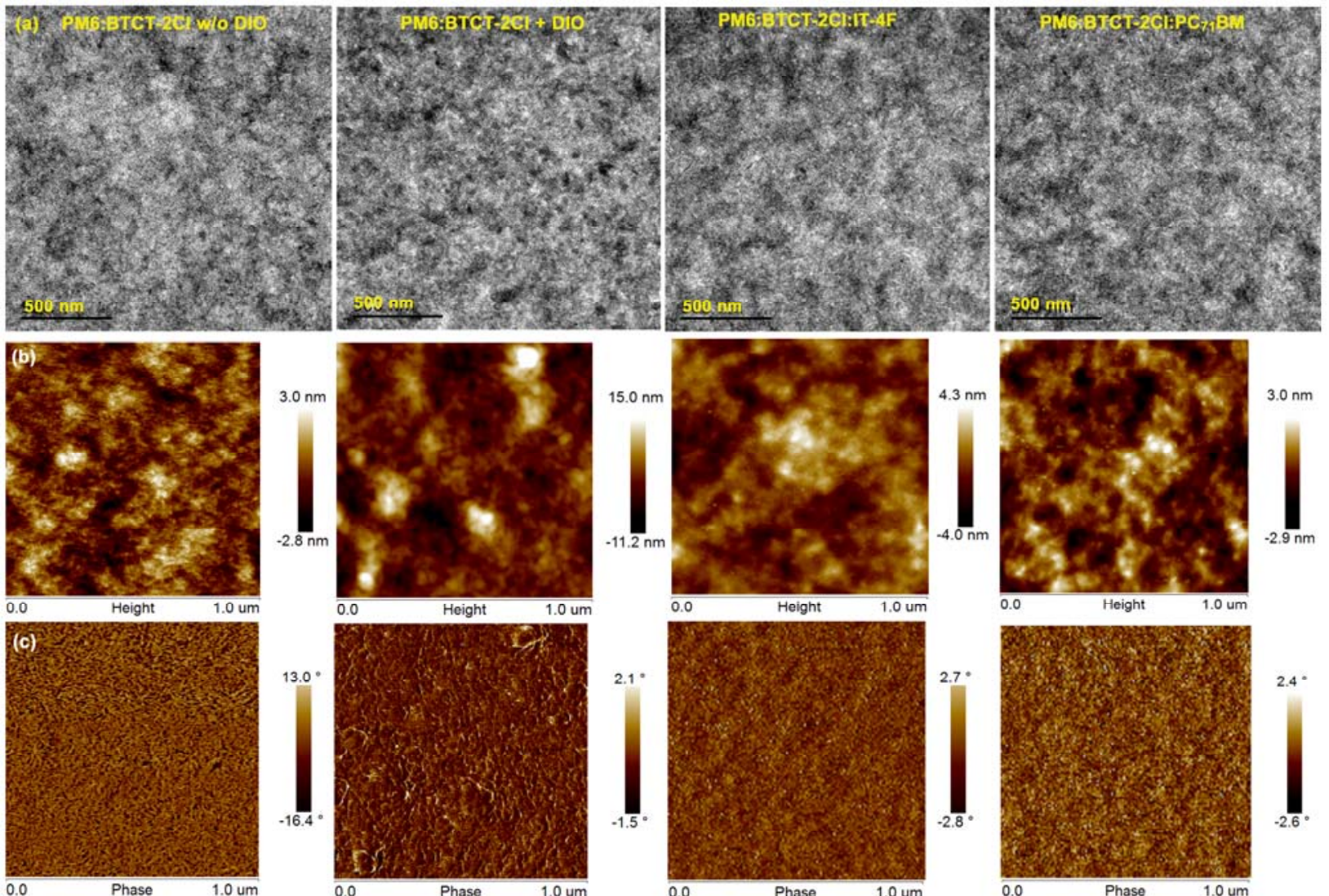

Figure S10. Plots of short-circuit current-density $\left(J_{\mathrm{sc}}\right)$ and open-circuit voltage $\left(V_{\mathrm{oc}}\right)$ vs. light intensity of the BTCT-2CI based binary (a) and ternary (b) devices.
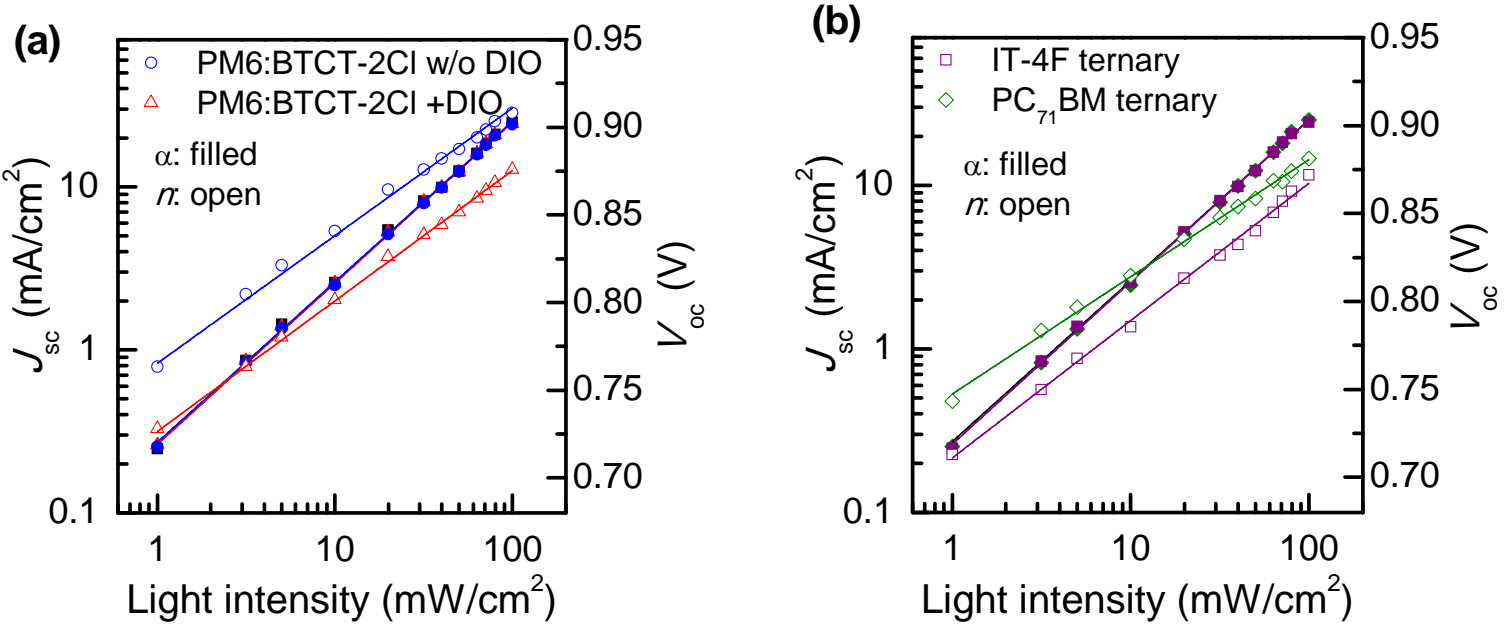


\section{Supporting Tables}

Table S1. The photovoltaic data of BTCT-2CI based solar cells with different optimized conditions.

\begin{tabular}{|c|c|c|c|c|c|c|c|}
\hline Entries & PM6:BTCT-2Cl & additive & $\begin{array}{c}\text { Spin Speed } \\
(\mathrm{rpm})\end{array}$ & Voc (V) & $\begin{array}{c}\text { PCE } \\
(\%)\end{array}$ & $\begin{array}{c}\text { FF } \\
(\%)\end{array}$ & Jsc $\left(\mathrm{mA} / \mathrm{cm}^{2}\right)$ \\
\hline 1.1 & $1: 1$ & $/$ & 2000 & 0.895 & 13.89 & 63.95 & 24.29 \\
\hline 1.2 & $1: 1$ & $/$ & 3000 & 0.901 & 14.39 & 65.66 & 24.32 \\
\hline 1.3 & $1: 1$ & $/$ & 4000 & 0.901 & 14.16 & 66.87 & 23.49 \\
\hline 1.4 & $1: 1.2$ & $/$ & 3000 & 0.898 & 14.33 & 65.59 & 24.33 \\
\hline 2.1 & $1: 1$ & $0.5 \% \mathrm{CN}$ & 3000 & 0.933 & 12.13 & 68.69 & 18.97 \\
\hline 2.2 & $1: 1$ & $1.0 \% \mathrm{CN}$ & 3000 & 0.934 & 11.96 & 67.88 & 18.86 \\
\hline 2.3 & $1: 1$ & $0.5 \% \mathrm{DIO}$ & 3000 & 0.876 & 15.02 & 70.32 & 24.38 \\
\hline 2.4 & $1: 1$ & $1.0 \% \mathrm{DIO}$ & 3000 & 0.872 & 14.91 & 70.51 & 24.17 \\
\hline 2.5 & $1: 1.2$ & $0.5 \% \mathrm{DIO}$ & 3000 & 0.875 & 14.95 & 70.17 & 24.35 \\
\hline
\end{tabular}

Table S2. Collections of the lifetimes $(\tau)$ and Amplitude (A) of fs-TA results.

\begin{tabular}{|c|c|c|c|c|c|c|c|c|c|}
\hline Actiev layer & $\begin{array}{c}\tau_{1} / \mathrm{ps} \\
(\text { rise })\end{array}$ & $\mathrm{A}_{1}$ & $\tau_{2} / \mathrm{ps}$ & $\mathrm{A}_{2}$ & $\tau_{3} / \mathrm{ps}$ & $\mathrm{A}_{3}$ & $\tau_{4} / \mathrm{ns}$ & $\begin{array}{c}\mathrm{A}_{4} \\
/ \mathrm{ns}\end{array}$ \\
\hline PC $_{71}$ BM ternary & $0.29 \pm 0.03$ & 1.60 & $47 \pm 2.6$ & $-1.40(42 \%)$ & $581 \pm 62$ & $-0.81(24 \%)$ & $23 \pm 3$ & $-1.11(34 \%)$ & 8 \\
\hline IT4F ternary & $2.0 \pm 0.2$ & 0.95 & $140 \pm 38$ & $-0.53(23 \%)$ & $943 \pm 331$ & $-0.68(30 \%)$ & $18 \pm 5$ & $-1.09(47 \%)$ & 9 \\
\hline Binary + DIO & $2.1 \pm 0.2$ & 0.87 & $91 \pm 14$ & $-0.69(44 \%)$ & $623 \pm 228$ & $-0.38(25 \%)$ & $19 \pm 6$ & $-0.48(31 \%)$ & 6 \\
\hline Binary w/o DIO & $1.1 \pm 0.3$ & 1.20 & $26 \pm 68$ & $-0.32(14 \%)$ & $161 \pm 35$ & $-1.04(48 \%)$ & $18 \pm 3$ & $-0.83(38 \%)$ & 7 \\
\hline
\end{tabular}

Table S3. Collections of results of the peak fitting of the GIWAXS profiles.

\begin{tabular}{|c|c|c|c|c|c|c|c|c|c|c|c|c|c|c|c|}
\hline & \multicolumn{3}{|c|}{ Neat } & \multicolumn{3}{|c|}{ Binary w/o DIO } & \multicolumn{3}{|c|}{ Binary + DIO } & \multicolumn{3}{|c|}{ IT-4F ternary } & \multicolumn{3}{|c|}{$\mathrm{PC}_{71} \mathrm{BM}$ ternary } \\
\hline Peak & $\left(\AA^{-1}\right)$ & $\begin{array}{c}d \\
(\AA)\end{array}$ & $\begin{array}{c}\text { CCL } \\
(\AA)\end{array}$ & $\left(\AA^{-1}\right)$ & $\begin{array}{c}d \\
(\AA)\end{array}$ & $\begin{array}{c}\text { CCL } \\
(\AA)\end{array}$ & $\left(\AA^{-1}\right)$ & $\begin{array}{c}d \\
(\AA)\end{array}$ & $\begin{array}{c}\text { CCL } \\
(\AA)\end{array}$ & $\left(\AA^{-1}\right)$ & $\begin{array}{c}d \\
(\AA)\end{array}$ & $\begin{array}{c}\text { CCL } \\
(\AA)\end{array}$ & $\left(\AA^{-1}\right)$ & $\begin{array}{c}d \\
(\AA)\end{array}$ & $\begin{array}{c}\text { CCL } \\
(\AA)\end{array}$ \\
\hline lamellar & 0.366 & 17.2 & 24.3 & 0.295 & 21.3 & 54.4 & 0.281 & 22.4 & 60.4 & 0.281 & 22.4 & 54.5 & 0.286 & 22.0 & 52.6 \\
\hline$\pi-\pi$ & 1.73 & 3.64 & 22.1 & 1.73 & 3.63 & 21.7 & 1.72 & 3.65 & 30.6 & 1.73 & 3.62 & 28.0 & 1.73 & 3.63 & 21.6 \\
\hline
\end{tabular}

\section{References}

1. Tan, Z.; Zhang, W.; Zhang, Z.; Qian, D.; Huang, Y.; Hou, J.; Li, Y., High-Performance Inverted Polymer Solar Cells with Solution-Processed Titanium Chelate as Electron-Collecting Layer on ITO Electrode. Advanced Materials 2012, 24, (11), 1476-1481.

2. Tang, A.; Zhan, C.; Yao, J., Comparative Study of Effects of Terminal Non-Alkyl Aromatic and Alkyl Groups on Small-Molecule Solar Cell Performance. Advanced Energy Materials 2015, 5, (13), 1500059.

3. Chen, Y.; Zhang, X.; Zhan, C.; Yao, J., Origin of Effects of Additive Solvent on FilmMorphology in Solution-Processed Nonfullerene Solar Cells. Acs Applied Materials \& Interfaces 2015, 7, (12), 6462-6471. 